\title{
Detection of Epstein-Barr virus genomes in AIDS related lymphomas: Sensitivity and specificity of in situ hybridisation compared with Southern blotting
}

\author{
S J Hamilton-Dutoit, H J Delecluse, M Raphael, G Lenoir, G Pallesen
}

\begin{abstract}
Eighteen cases of AIDS related, nonHodgkin's lymphomas were examined for the presence of Epstein-Barr virus (EBV) genomes using in situ hybridisation with a ${ }^{35}$ S-labelled probe. The results were compared with those obtained independently by Southern blot analysis with a ${ }^{32} \mathbf{P}$-labelled probe of frozen tissue from the same tumours. Technically satisfactory results were obtained with both methods in $15 \mathrm{lym}$ phomas. EBV DNA was detected in seven of $15(47 \%)$ cases by in situ hybridisation and in eight of $15(53 \%)$ cases by Southern blotting (including all the cases positive by in situ hybridisation). The results of EBV DNA detection by the two techniques were identical in 14 of 15 $(93 \%)$ cases. In situ hybridisation gave no false positive results.

This study shows that the sensitivity and specificity of in situ hybridisation for the detection of EBV genomes in AIDS related lymphomas approaches that of Southern blotting, even when using routinely processed archival, paraffin wax embedded material.
\end{abstract}

Epstein-Barr virus (EBV) has been implicated in the pathogenesis of a range of benign and malignant lymphoproliferative and epithelial lesions. ${ }^{1-11}$ Traditionally, the virus has been identified in tissues either by the use of immunocytochemistry to show the presence of EBV specific antigens in cytological preparations, or by the detection of EBV genomes in extracts of frozen tumour by filter-based nucleic acid hybridisation. Both these techniques require fresh or frozen tissue and this has limited the possibilities available for the study of EBV associated lesions in tissue sections.

Recently, methods have been described for showing the presence of EBV genomes in routinely processed paraffin wax embedded material by in situ hybridisation. ${ }^{71-19}$ This technique is potentially of great value because it allows retrospective studies to be carried out on archival pathological material, and it provides information on the nature and distribution of cells infected with EBV which is not available with other methods. We have previously shown the value of this technique for studying both epithelial and lympho- proliferative EBV associated lesions. ${ }^{11} 1216$ In particular, we have shown that about a half of AIDS related lymphomas contain EBV genomes, as detected by paraffin wax section in situ hybridisation with radiolabelled probes. ${ }^{17-19}$

While previous investigations have shown the potential of paraffin wax section in situ hybridisation, there have been no systematic studies to assess the specificity and sensitivity of this technique for showing the presence of EBV genomes compared with established methods using filter hybridisation. Previous studies of EBV genome positive, AIDS related lymphomas have found a range of viral copy numbers comparable with that found in other types of EBV associated lymphoproliferation. AIDS related lymphomas provide, therefore, a good model for testing the sensitivity of paraffin wax section in situ hybridisation when applied to lymphoproliferative disorders induced by EBV.

\section{Methods}

The tumours were selected from a series of over 100 cases of non-Hodgkin's lymphomas from patients seropositive for human immunodeficiency virus (HIV), collected by the French-Danish Study Group on the pathology of AIDS related lymphomas. Criteria for inclusion were the availability of both routinely processed, paraffin wax embedded material and snap frozen tumour tissue. These criteria were met in 18 cases. All were surgical biopsy specimens of non-Hodgkin's lymphomas, selected from the archives of several different institutions participating in the study. Tissue was routinely fixed and processed before paraffin wax embedding, although the procedures were not standardised. The fixative used in each case is shown in the table, although precise details of the protocol used were not available. Paraffin wax blocks had been stored for up to three years. Cases were classified according to the updated Kiel classification, ${ }^{20}$ with modifications as reported previously. ${ }^{19}$

The lymphomas were examined in separate laboratories for the presence of EBV DNA using both in situ hybridisation on paraffin wax sections and Southern blotting of snap frozen tissues. All studies were performed blind without knowledge of the results obtained in the other laboratory, and the findings were compared once all investigations had been completed. 
Histological type and results of EBV DNA detection by Southern blotting and paraffin wax section in situ hybridisation

\begin{tabular}{|c|c|c|c|c|c|}
\hline \multirow[b]{2}{*}{$\begin{array}{l}\text { Case } \\
\text { No }\end{array}$} & \multirow[b]{2}{*}{$\begin{array}{l}\text { Site of } \\
\text { lymphoma }\end{array}$} & \multirow[b]{2}{*}{$\begin{array}{l}\text { Lymphoma } \\
\text { histology }\end{array}$} & \multirow[b]{2}{*}{$\begin{array}{l}\text { Fiaxtive } \\
\text { used }\end{array}$} & \multicolumn{2}{|c|}{ Epstein-Barr virus DNA } \\
\hline & & & & $\begin{array}{l}\text { Southern } \\
\text { blotting }\end{array}$ & $\begin{array}{l}\text { In situ } \\
\text { hybridisation }\end{array}$ \\
\hline 1 & Lymph node & Burkitt & NBF & + & + \\
\hline 2 & Lymph node & Burkitt & NBF & + & + \\
\hline 3 & Lymph node & Immunoblastic (PC) & NBF & + & + \\
\hline 4 & Lung & Immunoblastic (PB) & $\mathrm{AAF}$ & + & + \\
\hline 5 & Palate & Immunoblastic (PB) & $\mathrm{AAF}$ & + & + \\
\hline 6 & Lymph node & Immunoblastic (PB) & NBF & + & + \\
\hline 7 & Gum & Immunoblastic (PB) & AAF & + & + \\
\hline 8 & Lymph node & Burkitt & NBF & + & - \\
\hline 9 & Lymph node & Burkitt & $\mathrm{NBF}$ & - & - \\
\hline 10 & Bone marrow & Burkitt & NBF & - & - \\
\hline 11 & Lymph node & Burkitt & NBF & - & - \\
\hline 12 & Muscle & Burkitt & $\mathrm{NBF}$ & NS & - \\
\hline 13 & Lymph node & Centroblastic & NBF & - & - \\
\hline 14 & Lymph node & Centroblastic & AAF & - & - \\
\hline 15 & Lymph node & Centroblastic & NBF & - & - \\
\hline 16 & Lymph node & Immunoblastic (PB) & NBF & - & - \\
\hline 17 & Gum & Immunoblastic (PB) & AAF & + & NS \\
\hline 18 & Gum & Immunoblastic (PB) & AAF & + & NS \\
\hline
\end{tabular}

The results of EBV DNA detection using in situ hybridisation and Southern blotting were in agreement in 14 of the 15 lymphomas which gave technically satisfactory analyses.

AAF = acetic acid, alcohol, formaldehyde (Lillie's AAF).

NBF = neutral buffered formalin.

NS $=$ not satisfactory.

$\mathrm{PB}=$ plasmablastic differentiation

$\mathrm{PC}=$ plasmacytic differentiation.

\section{PROBES}

EBV DNA was detected using EBV BamHI W probes specific for the viral internal repeats. For in situ hybridisation total plasmid DNA was labelled with ${ }^{35} \mathrm{~S}$-dCTP by nick translation ${ }^{21}$ to a specific activity of at least $1 \times 10^{9} \mathrm{dpm} / \mu \mathrm{g}$. For Southern blot analysis, probes were labelled with ${ }^{32} \mathrm{P}$-dCTP by the random primer method. ${ }^{22}$

For in situ hybridisation, probes for CMV ( $E c o R I J$ fragment of human cytomegalovirus and plasmid pBR322 (without the EBV insert) were used as negative controls.

\section{IN-SITU HYBRIDISATION}

ISH was performed on routinely fixed and processed, paraffin wax embedded tumour tissue as described previously. ${ }^{12}{ }^{19}$ Briefly, sections were cut onto slides coated with 3-aminopropyltriethoxysilane (Merck; Darmstadt, Germany) to prevent section loss, ${ }^{23}$ baked overnight at $65^{\circ} \mathrm{C}$, and dewaxed in xylene. Slides were incubated sequentially at room temperature in $0.2 \mathrm{~N} \mathrm{HCl}$ (10 minutes) and $0.01 \%$ Triton X-100 (90 seconds) with intervening washes in $2 \times \operatorname{SSC}(0.3 \mathrm{M}$ sodium chloride/ $0.03 \mathrm{M}$ sodium citrate, $\mathrm{pH} 7 \cdot 6$ ). Sections were digested in pronase $(1 \mathrm{mg} / \mathrm{ml}$; Boehringer Mannheim, Germany) for 10 minutes at $37^{\circ} \mathrm{C}$, washed in $2 \times \mathrm{SSC}$, acetylated with $0.1 \mathrm{M}$ triethanolamine $/ 0 \cdot 25 \%$ acetic anhydride for 10 minutes, and dehydrated. Hybridisation mixture $\left(40 \mathrm{ng} / \mathrm{ml}{ }^{35} \mathrm{~S}\right.$-labelled probe, $0.25 \mathrm{mg} / \mathrm{ml}$ salmon sperm DNA, $50 \%$ deionised formamide, $2 \times$ SSC, $10 \%$ dextran sulphate, and $50 \mathrm{mM}$ dithiothreitol) was applied under siliconised coverslips, and probe and tissue DNA were denatured simultaneously on a $90^{\circ} \mathrm{C}$ heating block for six minutes. After overnight hybridisation at $37^{\circ} \mathrm{C}$ coverslips were removed in $50 \%$ formamide $/ 0.1 \times \mathrm{SSC}$ at $37^{\circ} \mathrm{C}$ and then washed, first in $50 \%$ formamide $/ 0 \cdot 1 \times$ SSC, for four hours at $37^{\circ} \mathrm{C}$, and then in $2 \times$ SSC and $0.1 \times$ SSC, each for 30 minutes at room temperature. After dehydration in graded alcohols containing $0.3 \mathrm{M}$ ammonium acetate slides were dipped in Ilford G5 emulsion (with $0.3 \mathrm{M}$ ammonium acetate), exposed at $4^{\circ} \mathrm{C}$ for between two and eight days, developed in Kodak D19, fixed with Kodak rapid fixer, and counterstained with haematoxylin and eosin.

Cells were scored positive for viral DNA if they showed deposition of grains clearly in excess of the background level seen over random cells, and if hybridisation with the control probes was negative.

Controls: In all in situ hybridisation experiments the ${ }^{35} \mathrm{~S}$-labelled $\mathrm{CMV}$ and pBR322 probes were used on adjacent sections as negative probe controls. Sections of cells or tissues known to contain EBV-that is, oral hairy leucoplakia, acute infectious mononucleosis in tonsils, post transplantation lymphoma, or pellets of the EBV replicatively infected cell line P3HR1-were included in each batch of experiments as positive tissue controls. Non-hybridised sections and plain glass objective slides were included in each autoradiography batch as controls of background levels of signal. All slides were evaluated independently by two observers (SHD and GP). In cases of discrepancy, the case was re-examined by both observers and a consensus diagnosis reached.

\section{SOUTHERN BLOT ANALYSIS}

Total cellular and viral DNA was extracted from tumour samples (snap frozen after surgical removal) using standard procedures. ${ }^{24}$ Briefly, cell lysis and proteinase $\mathrm{K}$ digestion was followed by phenol/chloroform extraction and ethanol precipitation. Ten $\mu \mathrm{g}$ of DNA was digested with the restriction endonuclease $\mathrm{Bam}$ HI (Bethesda Research Laboratories; Gothersburg, MD, USA) according to the supplier's recommendations. Digested DNA was sizefractionated by electrophoresis on $0.7 \%$ agarose gels in TRIS-borate buffer, hydrolysed for 15 minutes in $0.25 \mathrm{~N} \mathrm{HCl}$, denatured for 30 
Figure 1 Partial involvement of a lymph node by Burkitt's type lymphoma in a patient with AIDS (case 1).

Paraffin wax section in situ hybridisation with ${ }^{35} S$ labelled EBV BamHI W probe. $(A)$ Infiltrating lymphoma contains $E B V$ $D N A$ in every cell as shown by heavy deposition of silver grains. Residual stroma (lower part of field) shows only background signal. (B) At high power all identifiable labelled (haematoxylin and eosin). tumour cells are heavily
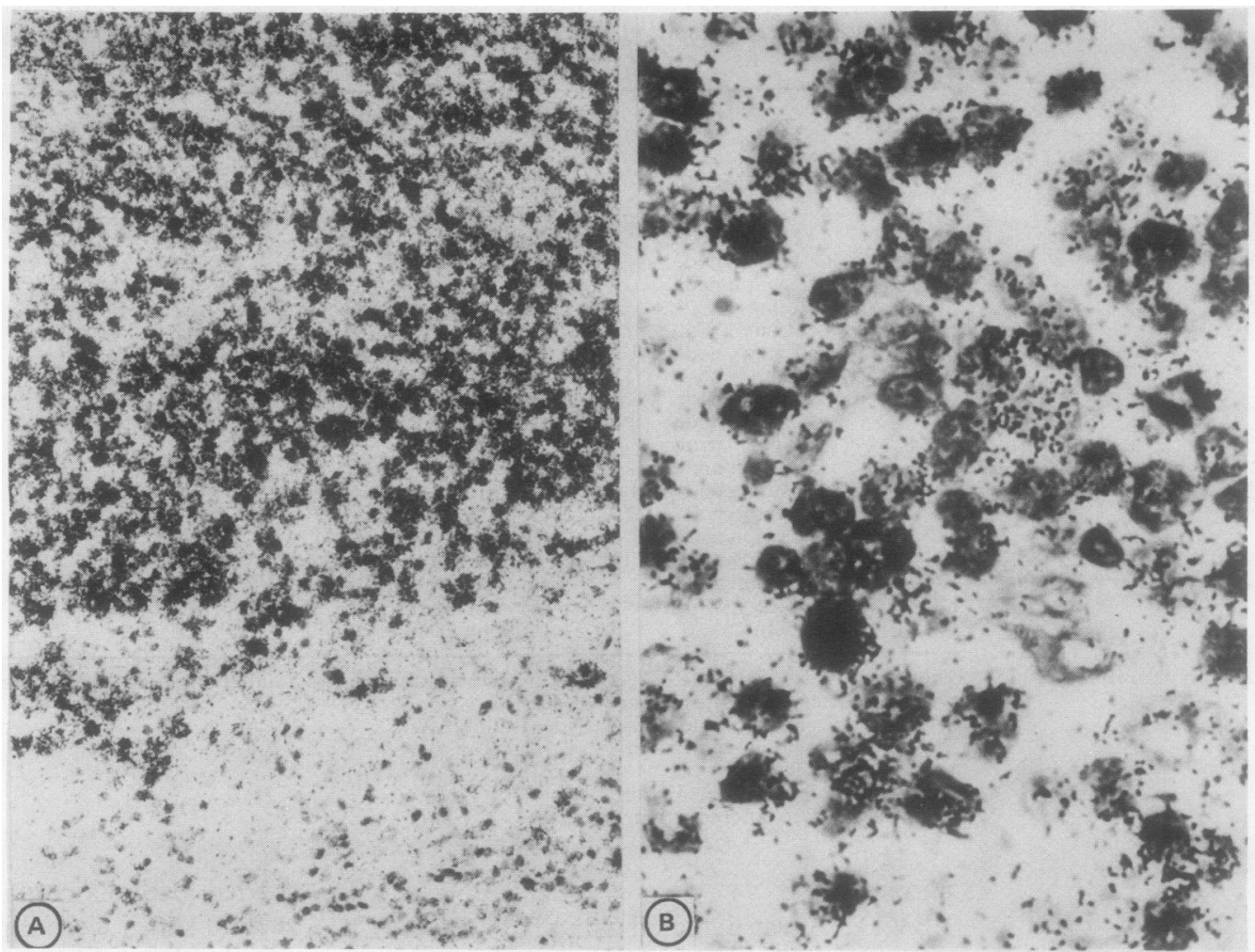

minutes before being transferred to nylon membrane (Hybond N, Amersham) according to the method of Southern. ${ }^{25}$ Filters were hybridised with ${ }^{32} \mathrm{P}$-labelled probe, as recommended by the manufacturer, and then washed at $60^{\circ} \mathrm{C}$ for 30 minutes each in $0.1 \% \mathrm{SDS} / 2 \times$ SSC and $0.1 \%$ SDS $/ 0.2 \times$ SSC. Hybridised probe was detected by autoradiography for one to three days at $-70^{\circ} \mathrm{C}$ using intensifying screens (Quanta III, Dupont; Wilmington, DE, USA).

Controls: Positive and negative controls for Southern blotting consisted of DNA extracted from Raji and BJAB cell lines, respectively.

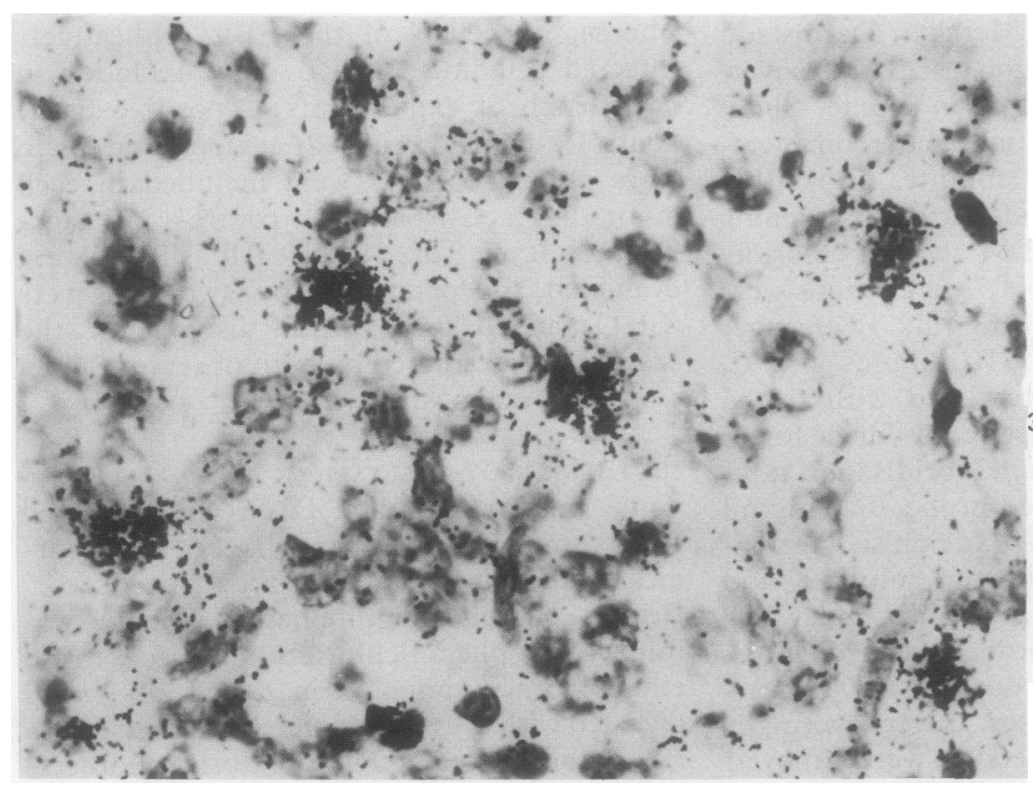

Figure 2 A polymorphic immunoblastic lymphoma with plasmablastic differentiation in an AIDS patient (case 4). Paraffin wax section in situ hybridisation with a ${ }^{35} S$-labelled $E B V B a n H I W$ probe shows the presence of $E B V$ genome. The hybridisation pattern is much more heterogenous than that seen in fig 1 , with scattered tumour blasts showing heavy autoradiographic labelling (haematoxylin and eosin).

\section{Results}

In two out of the 18 cases of AIDS related lymphomas in situ hybridisation was technically unsatisfactory because of high background signal in both test and control slides. In a third case Southern blot analysis could not be performed because of the poor yield of DNA extracted from the frozen block. Thus technically satisfactory results were obtained with

In situ hybridisation identified EBV genomes in tumour cells of seven of $15(47 \%)$ cases. As previously reported, ${ }^{19}$ there was considerable variation in the number and distribution of EBV positive cells both among cases (figs 1 and 2), and from field to field within the same tumour. Positive control tissues showed a hybridisation pattern identical with that reported previously. ${ }^{1216}$ No signal over background was detected in any of the EBV positive cases when the CMV and pBR322 probes were sub-

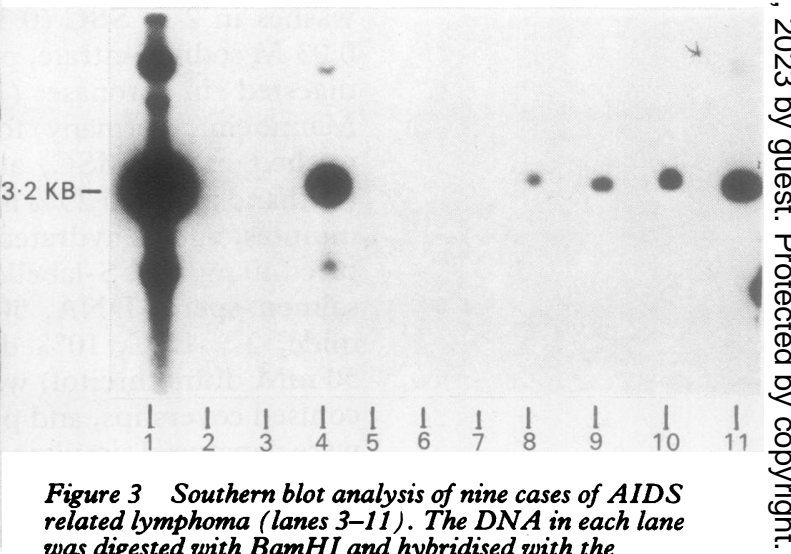
both techniques in 15 cases (table). BamHI W probe. Five tumours (lanes 4, 8-11) show a positive $3 \cdot 2$ kilobase pair band corresponding to the BamHI W fragment of $E B V$. Lanes 1 (Raji) and 2 (BJAB) contain positive and negative control DNA, respectively. 
stituted as negative controls for the EBV probe.

EBV DNA was detected in eight of $15(53 \%)$ tumours by Southern blotting, including all cases positive by in situ hybridisation. In positive cases a 3.2 kilobase pair DNA fragment could be shown by hybridisation of the $B a m H I W$ probes to BamHI digests (fig 3). This band was also found in control DNA known to contain EBV genomes, and corresponds to the reported size of the BamHIW fragment of isolated EBV DNA. EBV genomes were identified in one lymphoma (case 8 ) by Southern blot analysis, but not by in situ hybridisation. Thus the two techniques gave identical results in 14 out of the $15(93 \%)$ technically satisfactory cases.

\section{Discussion}

Traditionally, Southern blot analysis of DNA extracted from frozen tissue has been used as the "gold standard" when attempting to show the presence of viral genomes in tumours supposedly associated with EBV. The relative rarity of EBV associated lesions, however, combined with the need for frozen tissue for analysis, have made it difficult to collect large series of such cases. Paraffin wax section in situ hybridisation is, therefore, an attractive technique as it permits retrospective studies on archival material. Tissue structure is also maintained during in situ hybridisation and this, combined with the superior morphological detail of paraffin wax sections, allows viral sequences to be localised precisely within a tissue. Several recent studies have confirmed the value of paraffin wax section in situ hybridisation for EBV genome detection in both epithelial and lymphoproliferative lesions. ${ }^{71-19}$

Optimal conditions for performing EBV in situ hybridisation have been studied in various model experimental systems, ${ }^{26-29}$ but there have been no previous systematic investigations to compare the sensitivity of paraffin wax section EBV in situ hybridisation with Southern blot analysis in the same tumours. In our study these two techniques have identical results for EBV detection in 14 of 15 (93\%) cases of AIDS related lymphomas. The EBV carriage rates detected by in situ hybridisation and Southern blotting ( $47 \%$ and $53 \%$, respectively), however, are similar to those found in a larger series of AIDS related lymphomas. ${ }^{19}$ This suggests that the tumours in the present study can be taken to be representative of AIDS related lymphomas in general.

Discrepancies between the results of in situ hybridisation and Southern blot analysis might have been predicted in this study for several reasons. In general, the minimum average copy number per cell of a gene detectable by paraffin wax section in situ hybridisation will not be as low as that which can be shown by Southern blotting of fresh tissue. This is attributable to several factors, including the possible degradation of nucleic acids during fixation, the reduced access of probe to target DNA in fixed tissues, the restrictions placed on prehybridisation treatments by the need to retain good tissue morphology, and the introduction of increased background noise by the use of sensitive detection systems. This means that occasional lymphomas may exist in which tumour cells contain so few EBV copies that they fall below the limit of detection by in situ hybridisation, but they may still be identified by Southern blot analysis. Case 8 in our study may be an example of such a lymphoma.

On the other hand, the pattern of viral distribution in some tumours may mean that EBV can be detected by in situ hybridisation, but not by Southern blotting. This might occur if a tumour contains only very few EBV positive cells. The individual tumour cells may contain sufficient viral copies to be identified in sections by in situ hybridisation. When DNA is extracted for Southern blot analysis, however, these viral sequences may be so diluted by DNA from EBV negative cells as to be undetectable.

Another possible source of false negative results when using in situ hybridisation is related to fixation of the tissues. It has been shown that the sensitivity of in situ hybridisation is strongly affected by both initial delay in fixation and by the overall length of fixation..$^{30-32}$ Furthermore, certain fixatives such as Bouin's seem to be unsuitable if paraffin wax in situ hybridisation is subsequently used, possibly because they cause high levels of DNA degradation..$^{334}$ In our study fixation delay and overall fixation times for the different cases were not known. Standard prehybridisation procedures had, therefore, to be used, particularly with regard to the conditions of protease treatment used to expose target DNA. The close agreement of results obtained in this study by both in situ hybridisation and Southern blotting indicates that in most cases this did not affect the overall sensitivity of EBV detection. One lymphoma, which was negative by in situ hybridisation, was found to contain EBV by Southern blotting. Whether this false negative result was due to the tumour having a viral copy number below the detection limits by in situ hybridisation, or whether it reflected the use of an unusual fixation protocol is not clear.

We used ${ }^{35} \mathrm{~S}$-labelled probes in this study as in our experience these are more sensitive than non-isotopic probes for the detection of low abundance target sequences. ${ }^{16}$ Other groups have described the use of non-isotopic probes for EBV genome detection in lymphomas by paraffin wax section in situ hybridisation. ${ }^{14} 15$ Separate studies will be required to assess the sensitivity and specificity of these techniques.

We have only examined the sensitivity of paraffin wax section EBV in situ hybridisation when applied to AIDS related non-Hodgkin's lymphomas, but we believe these can be used as a model for lymphoproliferative disorders induced by EBV in general. Our results show that the sensitivity and specificity of paraffin wax section EBV in situ hybridisation using ${ }^{35} \mathrm{~S}$-labelled probes in these lesions approaches that of Southern blot analysis of frozen tissue extracts. This technique can, therefore, be used not only to provide information on the distribution and nature of cells infected with EBV in tissues, but also to identify EBV genome 
positive tumours when fresh or frozen tissue is not available to perform more traditional analyses.

This work was supported by the Danish Medical Research Council, the EEC (European Federation of AIDS Research), and the Lions Club of Denmark. Viral probes used in this study were provided by $\mathrm{Dr} G \mathrm{~W}$ Bornkamm, Freiburg, Germany (EBV) and Dr B Fleckenstein, Erlangen, Germany (CMV).

\section{Addendum}

After this paper had been accepted, we were able to re-examine DNA from case 8 with Southern blotting to estimate the EBV copy number. The tumour contained an average of less than two copies of EBV per cell compared with control cell lines, confirming that the failure of in situ hybridisation to detect EBV DNA in this case could be attributed to the low viral copy number present.

1 Epstein MA, Achong BG, Barr YM. Virus particles in cultured lymphoblasts from Burkitt's lymphoma. Lancet 1964;i:702-3.

2 Henle G, Henle W, Diehl V. Relation of Burkitt's tumorassociated herpes-type virus to infectious mononucleosis. Proc Natl Acad Sci USA 1968;59:94-101.

3 Saemundsen AK, Purtilo DT, Sakamoto K, et al. Documentation of Epstein-Barr virus infection in immunodeficien patients with life-threatening lymphoproliferative patients with life-threatening lymphoproliferative diseases by Epstein-Barr virus complementary RNA/ 1981;41:4237-42.

4 Ho M, Miller G, Atchinson RW, et al. Epstein-Barr virus infections and DNA hybridization studies in posttransplantation lymphoma and lymphoproliferative lesions: the role of primary infection. $J$ Infect Dis 1985;152:876-86.

5 Ziegler J, Beckstead J, Volberding P, et al. Non-Hodgkin' lymphoma in 90 homosexual men. Relation to generalized lymphadenopathy and the acquired immunodeficiency syndrome. N Engl J Med 1984;311:565-70.

6 Weiss LM, Strickler JG, Warnke RA, Purtilo DT, Sklar J. Epstein-Barr viral DNA in tissues of Hodgkin's disease. Am J Pathol 1987:129:86-91.

7 Weiss LM, Movahed LA, Warnke RA, Sklar J. Detection of Epstein-Barr viral genomes in Reed-Sternberg cells of Epstein-Barr viral genomes in Reed-Sternberg

8 Harabuchi Y, Yamanaka N, Kataura A, et al. Epstein-Bar virus in nasal $\mathrm{T}$-cell lymphomas in patients with lethal midline granuloma. Lancet 1990;335:128-30.

9 Greenspan JS, Greenspan D, Lennette ET, et al. Replication of Epstein "hairy" leukoplakia, an AIDS-associated lesion. $N$ Engl J Med 1985;313:1564-71.

10 zur Hausen H, Schulte-Holthausen H, Klein G, et al. EBV DNA in biopsies of Burkitt tumours and anaplastic carcinomas of the nasopharynx. Nature 1970;228:1056-8.

11 Hamilton-Dutoit SJ. Therkildsen $\mathrm{M}$, Nielsen $\mathrm{NH}$, Jensen H, Hansen JPH, Pallesen G. Undifferentiated carcinoma $H$, Hansen JPH, Pallesen G. Undiferentiated carcinoma tion of Epstein-Barr virus DNA by in situ hybridization. tion of Epstein-Barr virus
Hum Pathol (in press).

12 Niedobitek $G$, Hamilton-Dutoit $S$, Herbst $\mathrm{H}$, et al. Identification of Epstein-Barr virus infected cells in tonsils of acute infectious mononucleosis by in-situ hybridization. Hum Pathol 1989;20:796-9.

13 Weiss LM, Movahed LA. In situ demonstration of EpsteinBarr viral genomes in viral-associated B cell lymphoproliferations. Am J Pathol 1989;134:651-9.

14 Bashir R, Harris N, Hochberg F, Singer R. Detection of EB virus in four CNS lymphomas by in situ hybridisation. Neurology 1989;39:813-17.

15 Murphy JK, Young LS, Bevan IS, et al. Demonstration of Epstein-Barr virus in primary brain lymphoma by in situ hybridisation in paraffin wax embedded tissue. $J$ Clin Pathol 1990;43:220-3.

16 Hamilton-Dutoit SJ, Pallesen G. Detection of Epstein-Barr virus genomes in lymphoid and epithelial lesions using in situ nucleic acid hybridisation. In: Fenoglio-Preiser CM, Wolff M, Rilke F, eds. Progress in Pathology XII Philadelphia: Field and Wood 1991:97-128.

17 Hamilton-Dutoit SJ, Pallesen G, Karkov J, Skinhøj P, Franzmann $M$, Pedersen C. Identification of EBV-DNA in tumour cells of AIDS-related lymphomas by in-situ hybridisation. Lancet 1989;i:554-5.

18 Hamilton-Dutoit SJ, Karkov J, Franzmann MB, Pallesen G AIDS-related central nervous system lymphoma. AIDS-related central nervous system lymphoma. hybridisation. In: Racz P, Haase AT, Gluckman JC, eds. hybridisation. In: Racz P, Haase AT, Gluckman JC, eds. Modern pathology of AIDS

19 Hamilton-Dutoit SJ, Pallesen G, Franzmann MB, et al. AIDS-related lymphoma. Histopathology, immunophenotype, and association with Epstein-Barr virus as demonstrated by in situ hybridization. Am J Pathol 1991;138:149-63

20 Stansfeld AG, Diebold J, Kapanci Y, et al. Updated Kie Classification for lymphomas. Lancet $1988 ; \mathrm{i}: 292$

21 Rigby P, Dieckmann M, Rhodes C, Berg P. Labelling deoxyribonucleic acid to high specific activity in vitro by nick translation with $\mathrm{DNA}$ polymerase I $\mathrm{J}$ Mol Biol 1977;113:237-51.

22 Feinberg AP, Vogelstein B. A technique for radiolabelling DNA restriction endonuclease fragments to a high specific activity. Analyt Biochem 1983:132:6-13.

23 Rentrop M, Knapp B, Winter H, Schweizer J. Aminoalkylsilane-treated glass slides as support for in situ hybridization of keratin cDNAs to frozen tissue sections under varying fixation and pretreatment conditions. Histochem 1986;18:271-6.

24 Sambrook J, Fritsch E, Maniatis T. Molecular cloning. A laboratory manual. 2nd ed. New York: Cold Spring Harbor Press, 1989

25 Southern EM. Detection of specific sequences among DNA fragments separated by gel electrophoresis. $\mathrm{J} \mathrm{Mol} \mathrm{Biol}$ 1975;98:503-17.

26 Moar MH, Klein G. Detection of Epstein-Barr virus (EBV) DNA sequences using in situ hybridization. Biochim DNA sequences using in situ
Biophys Acta 1978;519:49-64.

27 Lawrence JB, Villnave CA, Singer R. Sensitive, highresolution chromatin and chromosome mapping in situ: Presence and orientation of two closely integrated copies of EBV in a lymphoma line. Cell 1988;52:51-61.

28 Bashir R, Hochberg F, Singer RH. Detection of EpsteinBarr virus by in situ hybridization. Progress towards development of a nonisotopic diagnostic test. Am J Pathol 1989;135:1035-44.

29 Teo CG, Griffin BE. Visualization of single copies of the Epstein-Barr virus genome by in situ hybridization. Analyt Biochem 1990;186:78-85.

30 Brigati DJ, Myerson D, Leary JJ, et al. Detection of vira genomes in cultured cells and paraffin-embedded tissue genomes in cultured cells and paraffin-embedded tissue Virology 1983;126:32-50.

31 Haase A, Brahic M, Stowring L, Blum $H$. Detection of viral nucleic acids by in situ hybridization. IN: Maramorosch $\mathrm{K}$, Koprowski H, eds. Methods in Virology, VII. New York: Academic Press, 1984:189-226.

32 Pringle JH, Homer CE, Warford A, Kendall CH, Lauder $\mathrm{I}$ In situ hybridization: alkaline phosphatase visualization of biotinylated probes in cryostat and paraffin sections. Histochem J 1987;19:488-96.

33 Nuovo GJ, Silverstein SJ. Comparison of formalin, buffered formalin, and Bouin's fixation on the detection of human papillomavirus deoxyribonucleic acid from genital lesions. Lab Invest 1988;59:720-4.

34 Nuovo GJ, Richart RM. Buffered formalin is the superio fixative for the detection of HPV DNA by in situ hybridization analysis. Am J Pathol 1989;134:837-42. 